\title{
Implementation of Fibonacci Retracements and Exponential Moving Average (EMA) Trading Strategy in Indonesia Stock Exchange
}

\author{
Lusindah and Erman Sumirat
}

\section{ABSTRACT}

\begin{abstract}
Based on KSEI statistic data on March 2021, IDX individual stock market investor is increasing $199 \%$ compared to 2018 becoming $4,848,954$ number of investors. $56.9 \%$ population of the individual investor is having ages that less than 30 years. In the period where IDX was bullish in November 2020 January 2021, there is a phenomenon where stocks influencers appeared in social media and impacted to the stock price movement after the announcement is done by the influencer. In contrary, during bearish and sideways condition, those influencers were gone and changed with bad news that went viral where many individual investors are lost their capital in IDX. They lose money since they are gambling in the stock market without any analysis and no establishment of trading plan. This research is aimed as a strategy to individual investors in IDX to implement trading strategy based on Fibonacci retracements and projections, EMA lines, trendlines, stochastic, and volume. Back testing is conducted in IDX SMC Liquid index constituents during January 2018 until December 2020 period. By implementing this trading strategy, return generated is $164 \%$ for 3 years trading time frame. Author also found that this trading strategy is effective in bullish trend condition especially for individual investors that have long position.
\end{abstract}

Keywords: EMA and Stochastic, Fibonacci retracement and projection, Indonesia Stock Exchange, Technical Analysis.

\section{INTRODUCTION}

Significant growth on number of investors seen on Indonesia Stock Exchange (IDX). Based on latest KSEI (Indonesia Central Security Depository) statistic data on March 2021, IDX individual stock market investor is increasing $199 \%$ compared to 2018 data becoming 4,848,954 number of investors. In late 2020, there is new term for new individual investor called investor Angkatan Covid-19. During IDX bullish trend in November 2021-first week of January 2021 period, there was increasing number of stock's influencer at social media who have impact to security price when they mentioned the ticker name. Any securities price will have significant price movement after the influencer did the announcements in their social media platform.

However, after this bullish trend in IDX, there were some bad news in mass media about the investor who lose their capital in stock market. "Viral Bunuh Diri Gegara Saham, Jadi Investor Harus Bagaimana?" [1]; "Gawat! Banyak Milenial Pakai Uang Kuliah dan Pinjol untuk Trading Saham" [2]. They made decision for trading by following influencer recommendation and it is a gambling in stock market.

By looking at this phenomena, Indonesia's investor tends to act short term for their stock investment. This is in line with research that was done by Utami [3] showing that Indonesian

\author{
Submitted : August 06, 2021 \\ Published : August 31, 2021 \\ ISSN: 2507-1076 \\ DOI: $10.24018 /$ ejbmr.2021.6.4.1033 \\ Lusindah* \\ School of Business and Management ITB, \\ Bandung, Indonesia. \\ (e-mail: lusindah-1@sbm-itb.ac.id) \\ Erman Sumirat \\ School of Business and Management ITB, \\ Bandung, Indonesia. \\ (e-mail: erman.sumirat ${ }^{@}$ sbm-itb.ac.id)
}

*Corresponding Author investors preferred to choose technical analysis than fundamental analysis. In her research $51.2 \%$ of population is using technical analysis and the rest of $48.8 \%$ population preferred to use fundamental analysis while investing in stock market [3]. Therefore, for short term investment purposes, Indonesia's investor shall have technical analysis competency.

In line with growth of number of investors in Indonesia, especially great increment during pandemic Covid-19, the number of average daily number of trades are also increasing. As depicted in Fig. 1, average daily number of trades is also increasing significantly. As per June 2021, average daily number of trades are 1,225,152 trades. Compared to 2020, which was 677,430 , the number of average daily number of trades is increasing $80 \%$. This is the evidence that almost investors in Indonesia are investing for short-term and not for long term purposes. If the investors in Indonesia are investing for long-term time frame, the average daily number of trades are not increase significantly.

Average of daily active investors in Indonesia is also having significant increase as shown in Fig. 2. In 2021, there are 201,000 average daily active investors trade in IDX. Compared to 2020, the average number of daily active investors is increasing $111 \%$. This number is also showing that most of Indonesia's investors are invest in IDX in short term time frame rather than long term time frame. Other 
evidence that strengthens this argument are the increased number of individual/retail investors as depicted in Fig 3. and the increased number of individual/retail investors trading value as depicted in Fig 4.

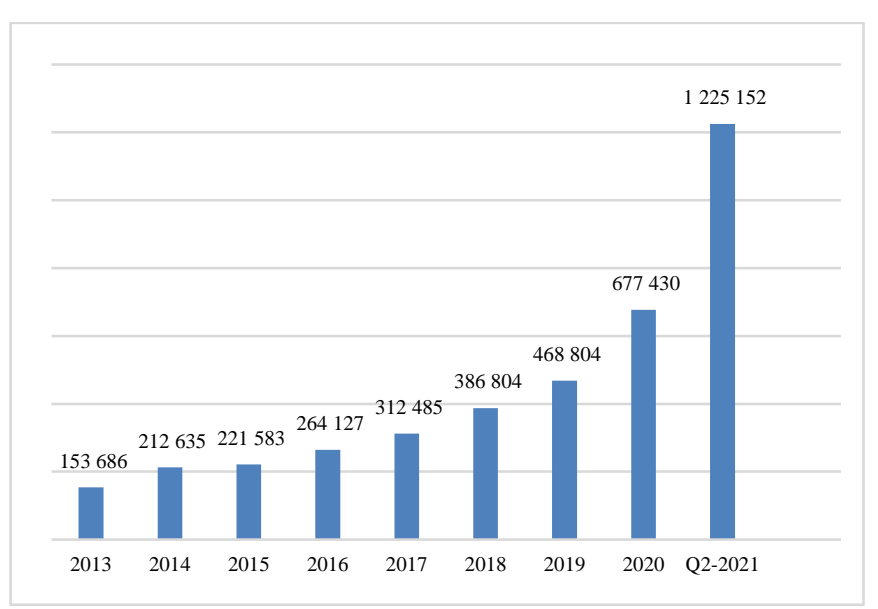

Fig. 1. Average Daily Number of Trade (2013-2021 Periods) [4].

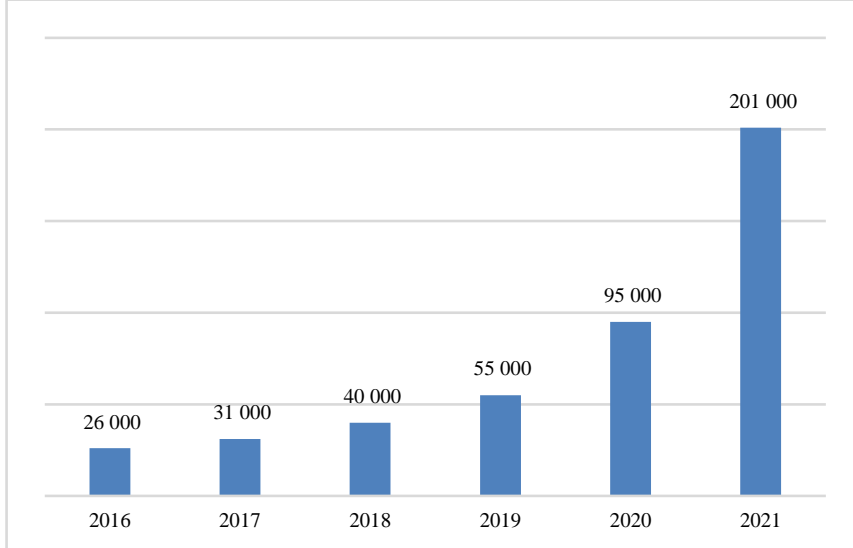

Fig. 2. Average of Daily Active Investor (2016-2021 Periods) [5].

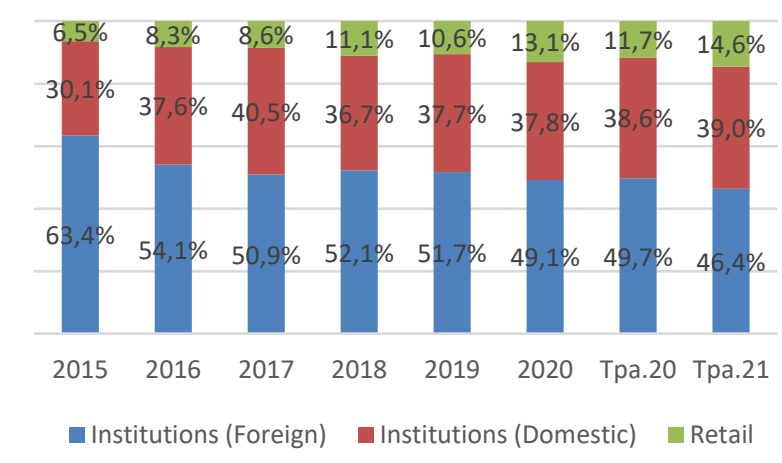

Fig. 3. IDX Investors Ownership [5].

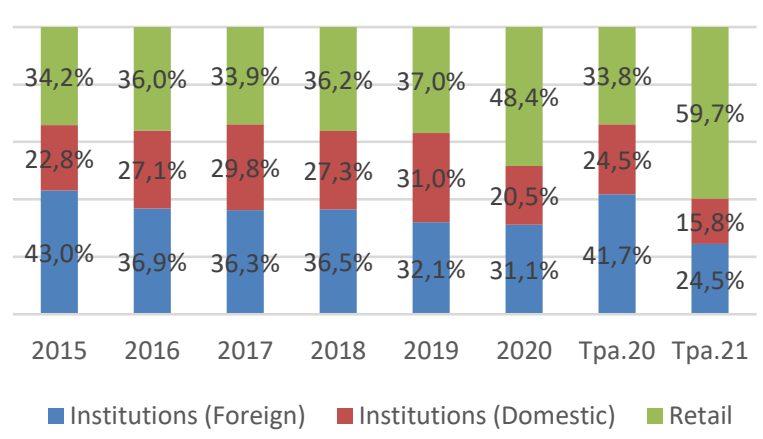

Fig. 4. IDX Investors Ownership [5].
Chung and Wang [6] found that, in South Korean market, the increase of number of trades and investors is the implication that individual investors are trade in a short-term time frame. In Indonesia, it is also observed that individual investors in Indonesia are doing trade frequently for short time frame rather than holding it for longer time frame [7].

For short-term investment time frame, technical analysis is widely used since the purposes is for trading and gaining return for short time period while fundamental analysis is used for investment in longer time period with buy and hold strategy without paying attention to daily price fluctuation [8].

Author hopes that this research will give knowledge to short-term individual investors that trade in IDX using technical analysis by using Fibonacci retracement and projections, Exponential Moving Average (EMA), trendline, and stochastics Indicator's despite of doing speculations and gambling in their trade.

\section{LITERATURE REVIEW}

\section{A. Dow Theory}

Dow Theory is used as fundamental technical analysis as method of identifying major or primary trend in the stock market. Charles H. Dow (1851-1902) made investment analysis about stock market analysis that was published in a series of Wall Street Journal editorials [9].

The six basic tenets of Dow Theory are the price discount everything, the market has three trends (bullish, sideways, and bearish trend), major trend has three phases (accumulation, participation, and distribution phase), the price must confirm each other, volume must confirm the trend, trend will move until it gives reversal signal [9].

\section{B. Fibonacci Ratio and Retracement}

Price do not move in straight line but usually retrace in the direction where price come. It will provide the trader opportunity to enter and exit the trade. Trend-following strategy is the trade strategy with entry point when there is a price correction with assumption that after correction or secondary reaction then the market will go up or down to continue the primary trend. Fibonacci retracements are run from low-to-high swing in uptrend and high-to-low swing in downtrend using ratio $0.328,0.50,0.618$, and 0.786 (if the swing is relatively long some time using ratio 0.236) [10]. The function of Fibonacci retracement is to identify potential support and support in secondary reaction (pull back).

Each percentage of correction that will be used have different risk profile for stop loss protection. Fig. 5 shows the different risk profile versus percentage of correction.

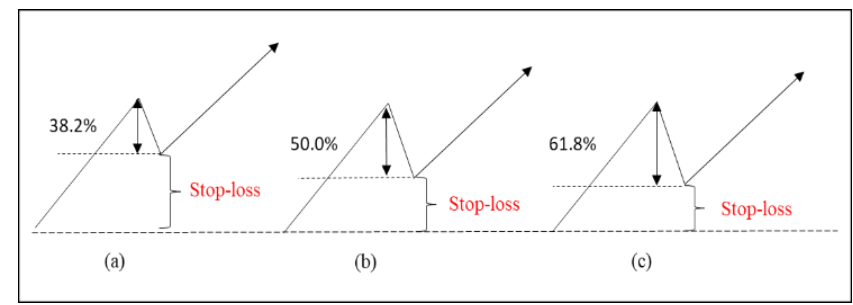

Fig. 5. Risk Profile Variation in Fibonacci Retracement 38.2\%, 50.0\%, and $61.8 \%$ application. 
No exact correction percentage, sometimes it is too early if applying entry point at $38.2 \%$ or too late if waiting retracement or correction at $61.8 \%$ that can cause missing the opportunity in strong trend.

\section{Fibonacci Extension}

Similar with Fibonacci retracement, Fibonacci extension run for possible support or resistance both in bullish and bearish market. Extension ratios are 1.272 and 1.618 for potential support or resistance from prior swing low-to-high or high-to-low [10]. Ratio of 2.618 and 4.618 sometimes are used for third target and very extended move that might be as final swing [11].

\section{Fibonacci Price Projections}

The Fibonacci price projection come up from three data points from comparing the swings in same direction of trend. The three points moved from low-to-high-to low swings in uptrend and from high-to-low-to-high swings in downtrend. The projections looking for potential support or resistance by using ratio 1.00 and 1.618 [12]. Symmetry or similarity of comparing swings in the same direction use ratio $100 \%$ in Fibonacci price projection.

\section{E. Exponential Moving Average}

EMA indicator is one type of moving average with greater weight for the most recent price while past price data is weighted less [11]. The longer EMA period can be used as a strong support signal, while the shorter EMA period can be used as a short-term trending signal. Buying signal are when EMA period is crossing above the longer EMA period (golden cross), while selling signal is when the shorter EMA period is crossing below the longer EMA period (death cross).

\section{F. Stochastic}

This indicator will show the relation between the last closing price with the highest price and the lowest price within a certain period [13]. The latest closing price that tends to be near the highest price will indicate a buying pressure or bullish sign while the latest closing price that tend to be near the lowest price will indicate a selling pressure or bearish sign [13].

A buying signal, or golden cross sign, is defined when $\% \mathrm{~K}$ line is crossing above the $\% \mathrm{D}$ line. In reverse, a selling signal or death cross sign is defined when $\% \mathrm{~K}$ line is crossing below the $\% \mathrm{D}$ line.

Framework that will be used in this research is as depicted in Fig. 6.

\section{Methodology}

The methodology used in this research are as follow:

1. The stocks that will be analyzed in this portfolio are the stocks that were constituents of IDX SMC Liquid as of February 2019.

2. Stocks price data movement will be the prices from 2018 to 2020 periods.

3. Screen the stocks listed in IDX SMC Liquid with weekly time frame.

4. Verify the stocks that were in weekly bullish trend by using EMA-13, 21, 34, and 90 indicators, shorter EMA time frame indicator shall be above longer EMA time frame to ensure that the trend is bullish.

5. Trade positions only made for stocks that are in their weekly bullish trend.

6. Capital that will used for trade is assumed to be equally weighted with initial capital IDR 10 million and the returns will be then used for the next trade capital.

7. Stocks' candidates will be verified in daily time frame chart to determine the entry (buying) position. Trades only be executed when in daily chart also showing bullish trend that are verified when shorter EMA time frame is above the longer EMA time frame indicators.

8. Trades' entry point (buying signal) is generated when the primary trend is entering its secondary trend. Buying position will be made when the stocks' prices are retraced to support level as depicted in Fibonacci ratio either $32.3 \%$ or $50 \%$ or $61.8 \%$.

9. Stop loss will be implemented with assumption using Author's risk profile.

Stocks that are passed with weekly bullish screening are ACES, BNLI, BRPT, BTPS, ERAA, HOKI, HRUM, INCO, MAIN, MCAS, PNBN, TINS, TKIM, WOOD.

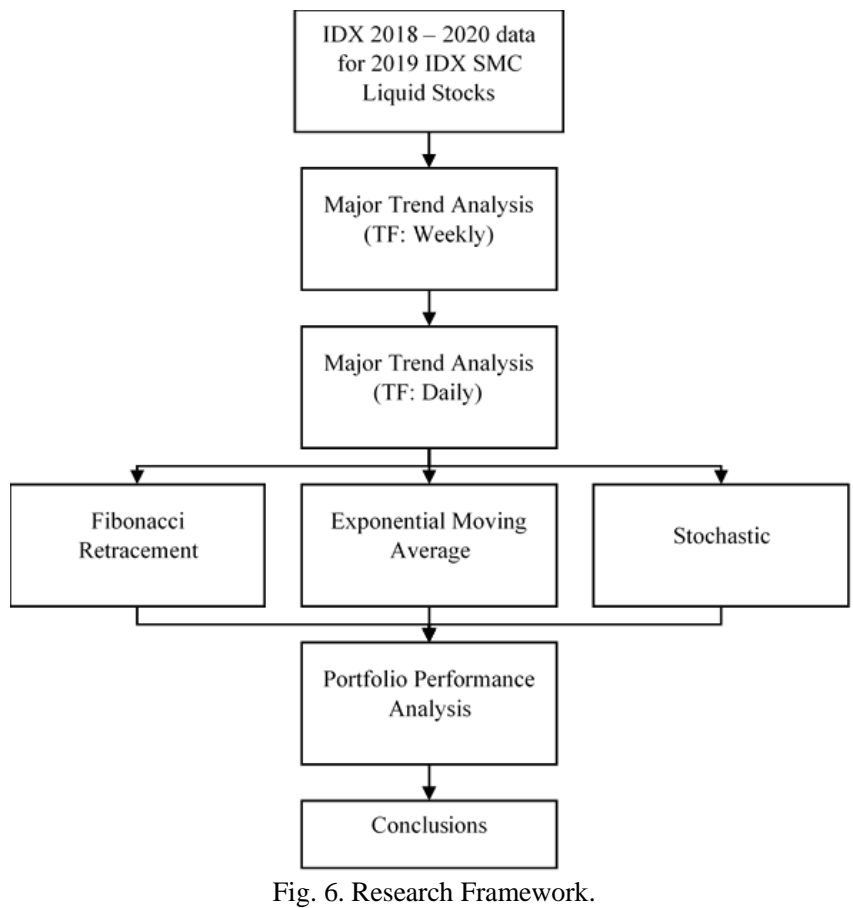

\section{RESUlt AND DisCUSSION}

Below is the sample of trading plan used in this research based on Fibonacci retracement, EMA, and Stochastic indicator.

\section{A. ACES (Ace Hardware Indonesia, Tbk)}

Fig. 7 is showing analysis using Fibonacci retracement for entry point and Fibonacci external retracement used in the second trade March $7^{\text {th }}, 2018$. Entry for this trade is IDR 1285 , selling profit target IDR 1475, and stop loss is set at IDR 1245. In this second trade, the target price did not achieve but stop at IDR 1245 or loss $-3 \%$. 


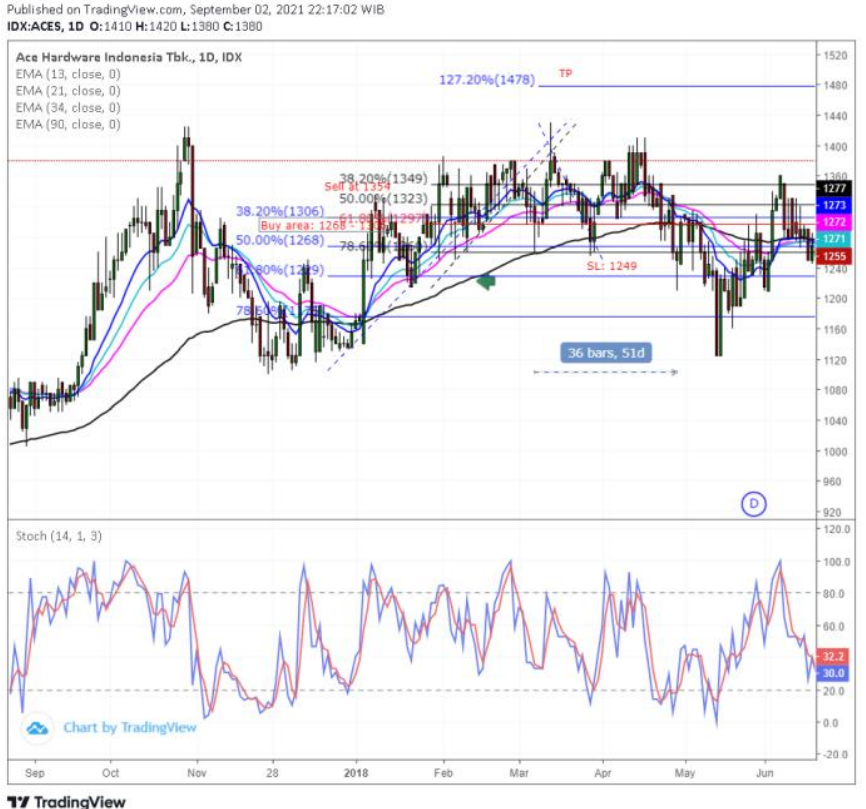

Fig. 7. ACES Trade on March 7th, 2018 [14].

Fig. 8 is showing sample second trade in ACES stock using Fibonacci retracement. Trade is set with entry point IDR 1380, selling target price IDR 1720 and stop loss is set at IDR 1340 with trading duration 98 days. Target is achieved at IDR 1720 with gain $25 \%$

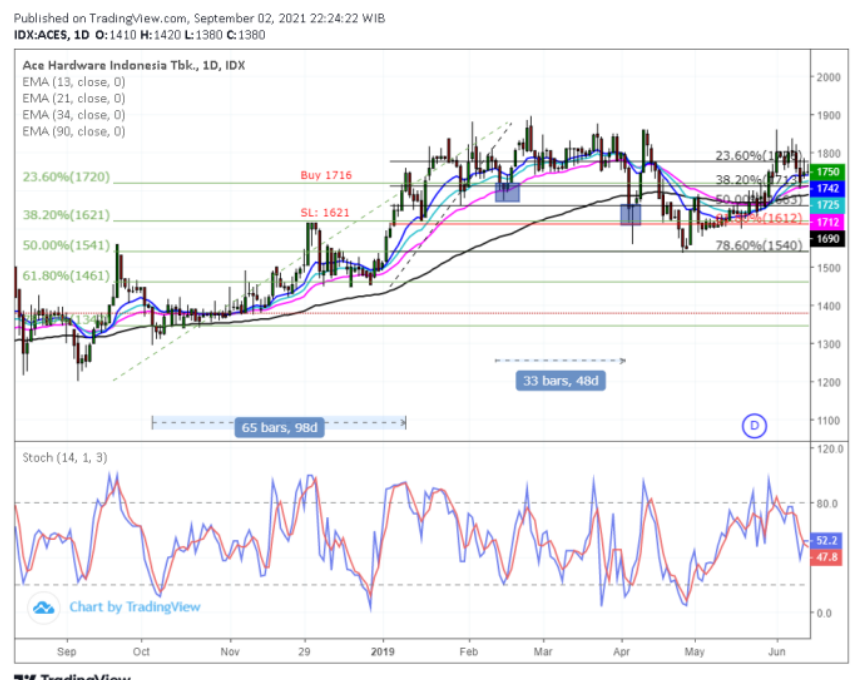

Fig. 8. ACES Trade on October 15th, 2018 [14].

\section{B. BNLI (Bank Permata, Tbk)}

BNLI is showing uptrend condition as depicted in Fig. 9. Using Fibonacci cluster, buying price is set at IDR 845, profit target-1 is set at IDR 1045 and stop loss-1 at IDR 960, profit target- 2 is set at IDR 1195 and stop loss-2 is set at IDR 1125 . This strategy is achieved by using trailing stop or by updating stop loss manually in the online trading system based on closing price. In this trade, all target derived from Fibonacci external retracement achieved with gain $41 \%$.

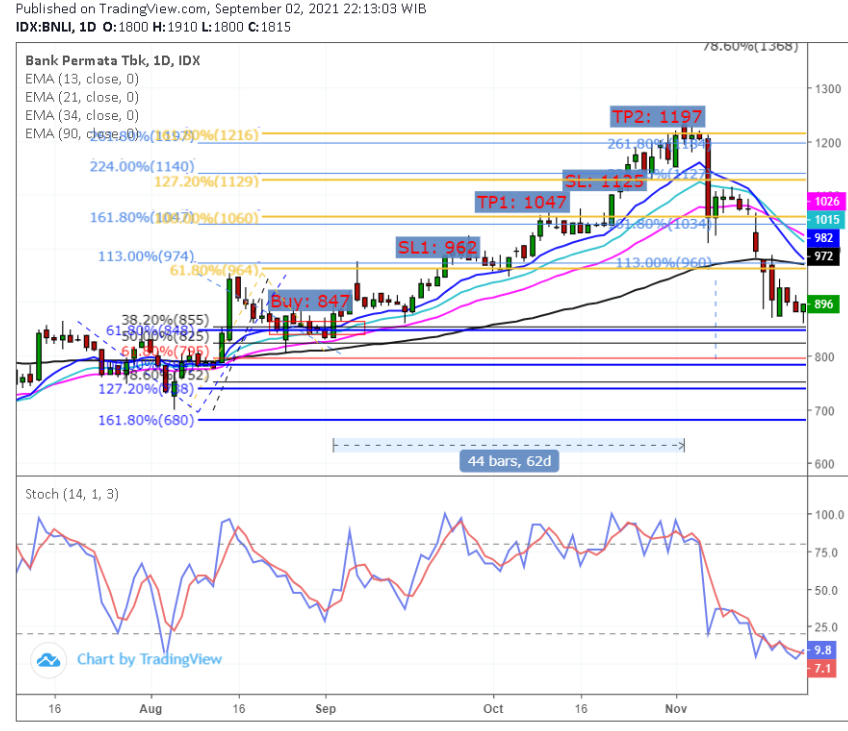

1\% TradingView

Fig. 9. BNLI Trade on September $3^{\text {rd }} 2019$ [15].

\section{BTPS (Bank Tabungan Pensiun Nasional, Tbk)}

In 2018, BTPS was showing uptrend phase. Buy signal is given when the stock price moves to Fibonacci retracement ratio $78.60 \%-61.8 \%$ and also confirmed by stochastic indicator signal that showing in oversold zone.

Buying area is defined within IDR 1595 - 1615 range, with stop loss set at IDR 1570. Profit target-1 is defined with Fibonacci external retracement ratio $161.8 \%$ at price IDR 1755. Target price is triggered, and stochastic indicator give a confirmation signal in overbought area with death cross line showing selling signal. In this trade, $9 \%$ profit is achieved.

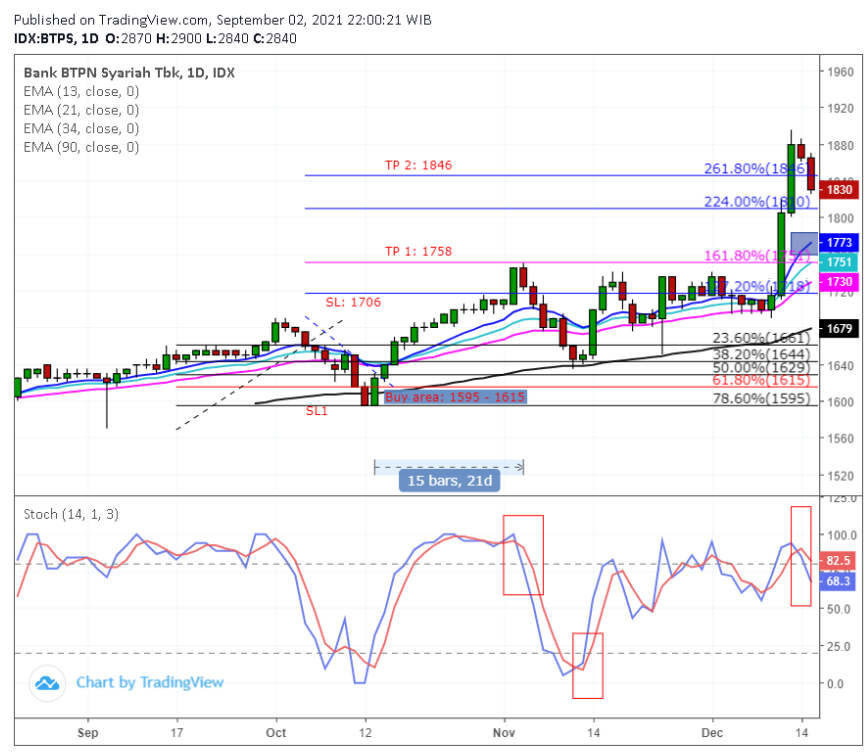

7y TradingView

Fig. 10. BTPS Trade on October $15^{\text {th }} 2018$ [16].

\section{WOOD (Integra Indocabinet, Tbk)}

WOOD buying price is set at IDR 288 using Fibonacci cluster with target selling price at $161.80 \%$ ratio Fibonacci external retracement and $100 \%$ Fibonacci projection or IDR 416. At this selling target, even already exit the trade, stochastic did not give any confirmation about reversal. Trade stopped with gain $44 \%$. 
Second trade in WOOD stock is traded on July $3^{\text {rd }}, 2018$. Entry point is occurred during price correction after several days from swing high. Buying price is set at IDR 462, stop loss is set at IDR 414 and selling price target is set at IDR 610. Trade stopped with gain $32 \%$.

\section{E. ERAA (Era Jaya Swasembada, Tbk)}

Using Fibonacci retracement and projection cluster, trade in ERRA stock is set with buying price area at IDR 190, stop loss at IDR 175, target price-1 at IDR 222 and target price-2 at IDR 256. In this trade, trade stop by selling at IDR 256 since stochastic indicator is showing death-cross or selling signal triggered. Profit generated from this trade is $35 \%$ for five days duration.

Fibonacci retracement and Fibonacci projection are the main indicators for trading's entry buy and sell while EMA line is used as a major trend indication and stochastic indicator is used as secondary confirmation. The trades are only occurred during bullish trend. Fibonacci retracement ratio $50 \%$, mostly can be used as a reference for partial entry point.

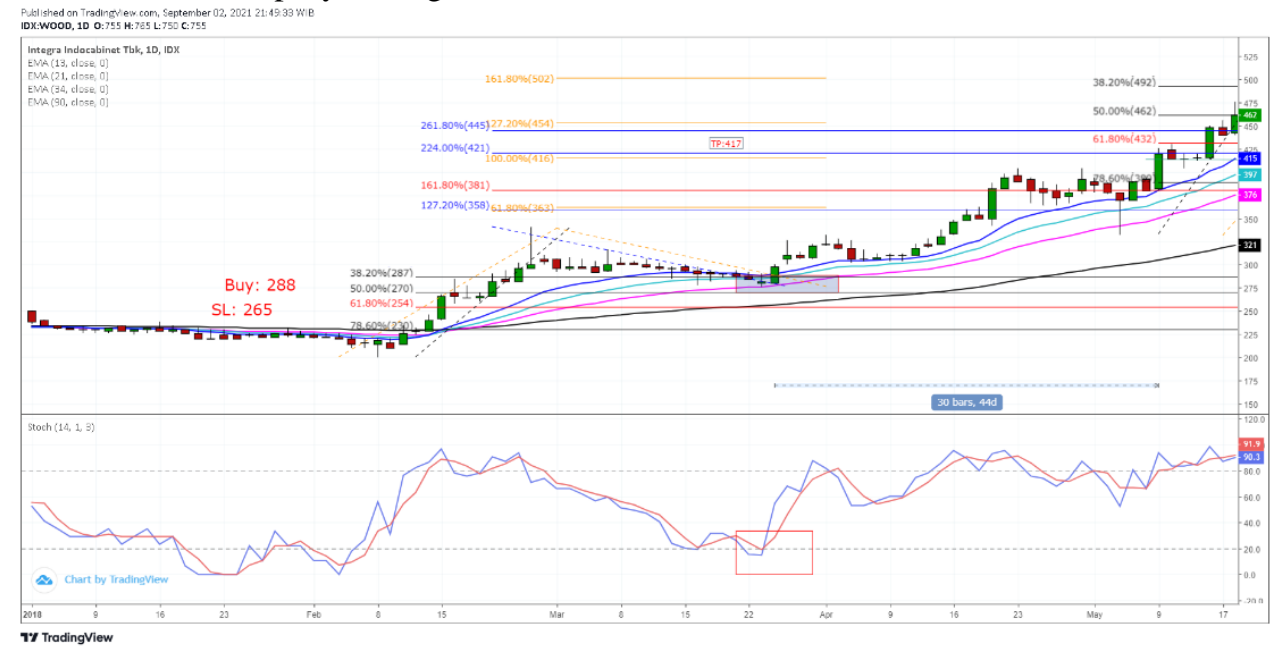

Fig. 11. WOOD Trade on March $26^{\text {th }}$, 2018 [17].

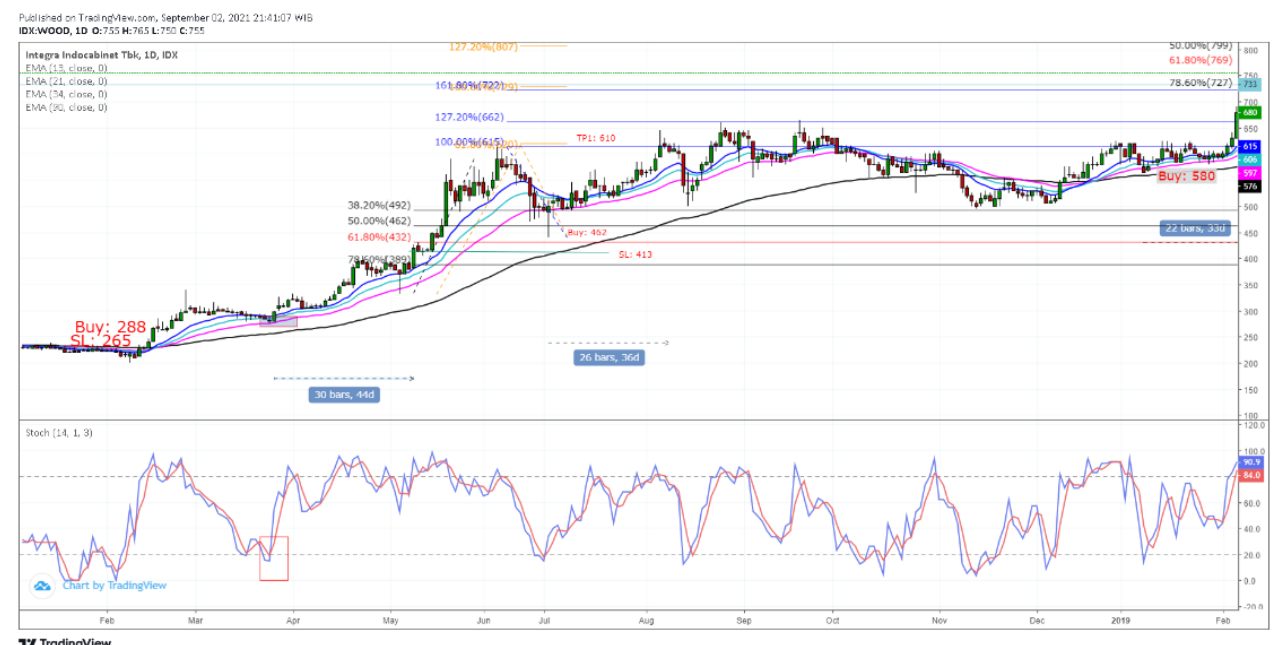

Fig. 12. WOOD Trade on July $3^{\text {rd }}, 2018$ [17].

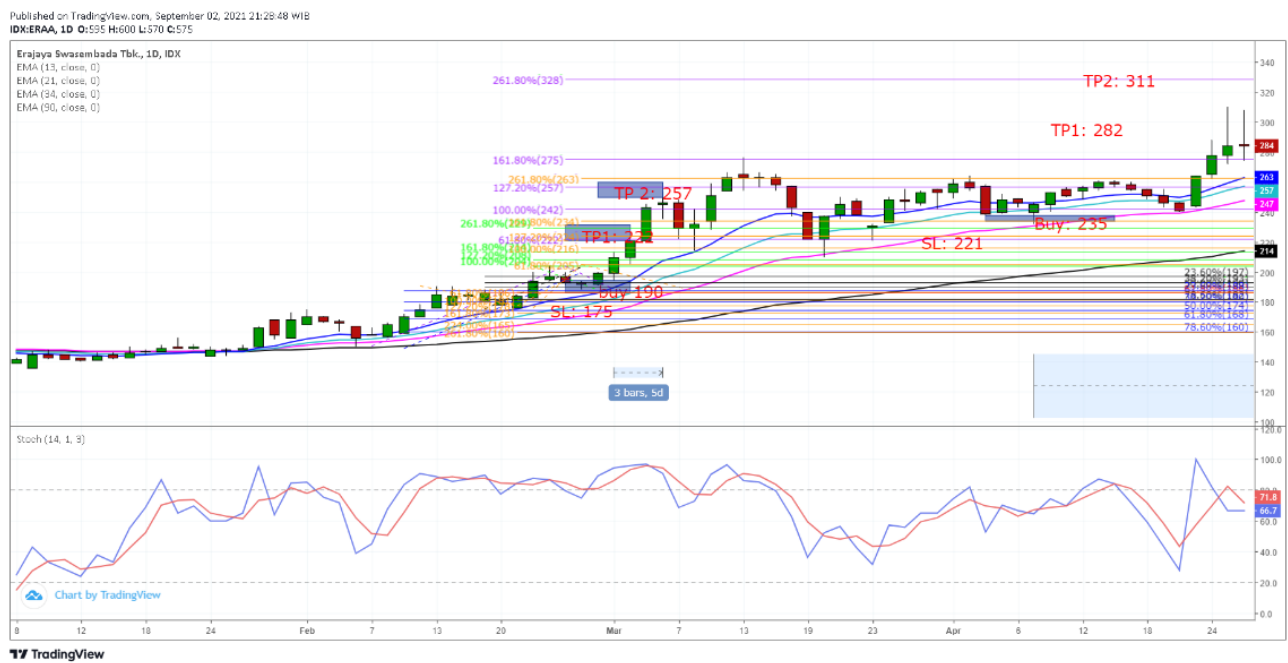

Fig. 13. ERAA Trade on March 1 ${ }^{\text {st }}, 2018$ [18]. 
From 73 trades made during research period, there are 10 trades loss and 63 trades gain. Winning rate by using this method is $86 \%$ with cumulative return $165 \%$ from initial capital. Details on trade journal used on this research can be seen in Table I.

TABLE I: COMPLETE TRADE JOURNAL 2018-2020 PERIOD

\begin{tabular}{|c|c|c|c|c|c|c|}
\hline Stocks & Date & Buy & Sell & Date & $\mathrm{G} / \mathrm{L}$ & Market \\
\hline ACES & 22-Jan-18 & 1230 & 1350 & 31-Jan-18 & $10 \%$ & $2 \%$ \\
\hline ACES & 07-Mar-18 & 1285 & 1245 & 10-Jan-19 & $25 \%$ & $11 \%$ \\
\hline ACES & 12-Jun-20 & 1405 & 1825 & 15-Dec-20 & $30 \%$ & $25 \%$ \\
\hline BNLI & 03-Sep-19 & 845 & 1195 & 04-Nov-19 & $41 \%$ & $-1 \%$ \\
\hline BNLI & 04-Nov-20 & 1895 & 2690 & 28-Dec-20 & $42 \%$ & $53 \%$ \\
\hline BRPT & 18-Dec-18 & 410 & 474 & 20-Dec-18 & $16 \%$ & $1 \%$ \\
\hline BRPT & 09-Jan-19 & 462 & 539 & 14-Feb-19 & $17 \%$ & $2 \%$ \\
\hline BRPT & 05-Apr-19 & 670 & 790 & 28-May-19 & $18 \%$ & $-7 \%$ \\
\hline BRPT & 09-Oct-19 & 905 & 1385 & 28-Nov-19 & $53 \%$ & $-1 \%$ \\
\hline BRPT & 02-Nov-20 & 884 & 1140 & 26-Nov-20 & $29 \%$ & $26 \%$ \\
\hline BRPT & 01-Dec-20 & 1045 & 1240 & 11-Dec-20 & $19 \%$ & $13 \%$ \\
\hline BTPS & $15-O c t-18$ & 1605 & 1755 & 05-Nov-18 & $9 \%$ & $3 \%$ \\
\hline BTPS & 14-Nov-18 & 1650 & 1835 & 17-Dec-18 & $11 \%$ & $4 \%$ \\
\hline BTPS & 20-Dec-18 & 1800 & 3160 & 31-Jul-19 & $76 \%$ & $4 \%$ \\
\hline BTPS & 23-Oct-19 & 3560 & 4370 & 19-Dec-19 & $23 \%$ & $0 \%$ \\
\hline BTPS & 03-Feb-20 & 4390 & 4525 & 07-Feb-20 & $3 \%$ & $-2 \%$ \\
\hline BTPS & 16-Jun-20 & 3160 & 3860 & 10-Aug-20 & $22 \%$ & $22 \%$ \\
\hline BTPS & 02-Nov-20 & 3670 & 4260 & 10-Nov-20 & $16 \%$ & $16 \%$ \\
\hline ERAA & 01-Mar-18 & 190 & 256 & 06-Mar-18 & $35 \%$ & $-2 \%$ \\
\hline ERAA & 09-Apr-18 & 236 & 488 & 28-Jun-18 & $107 \%$ & $-9 \%$ \\
\hline ERAA & 06-Jul-20 & 248 & 310 & 22-Jul-20 & $25 \%$ & $22 \%$ \\
\hline ERAA & 03-Aug-20 & 278 & 374 & 20-Nov-20 & $35 \%$ & $22 \%$ \\
\hline ERAA & 30-Nov-20 & 336 & 455 & 28-Dec-20 & $35 \%$ & $37 \%$ \\
\hline HOKI & 06-Feb-18 & 98 & 128 & 02-Mar-18 & $31 \%$ & $2 \%$ \\
\hline HOKI & 19-Mar-18 & 132 & 144 & 27-Apr-18 & $9 \%$ & $-6 \%$ \\
\hline HOKI & 28-Jun-18 & 206 & 240 & 03-Aug-18 & $17 \%$ & $24 \%$ \\
\hline HOKI & 29-May-19 & 170 & 200 & 11-Jul-19 & $18 \%$ & $23 \%$ \\
\hline HOKI & 22-Jul-19 & 200 & 230 & 14-Oct-19 & 0.15 & $15 \%$ \\
\hline HOKI & 30-Sep-20 & 190 & 220 & 23 -Oct-20 & $16 \%$ & $17 \%$ \\
\hline HOKI & 04-Nov-20 & 212 & 252 & 03-Dec-20 & $19 \%$ & $22 \%$ \\
\hline HRUM & 12-Jan-18 & 2340 & 2640 & 22-Jan-18 & $13 \%$ & $2 \%$ \\
\hline HRUM & 17-Sep-20 & 1640 & 1780 & 20-Oct-20 & $9 \%$ & $16 \%$ \\
\hline HRUM & 26-Nov-20 & 2260 & 2760 & 30-Nov-20 & $22 \%$ & $21 \%$ \\
\hline INCO & 26-Apr-18 & 3270 & 4220 & 03-Aug-18 & $29 \%$ & $2 \%$ \\
\hline INCO & 26-Aug-19 & 3177 & 3910 & 02-Sep-19 & $23 \%$ & $1 \%$ \\
\hline INCO & 03-Jun-20 & 2880 & 3850 & 27-Aug-20 & $34 \%$ & $33 \%$ \\
\hline INCO & 10-Sep-20 & 3620 & 4390 & 14-Oct-20 & $21 \%$ & $15 \%$ \\
\hline INCO & $16-$ Oct- 20 & 4040 & 5310 & 11-Dec-20 & $31 \%$ & $32 \%$ \\
\hline MAIN & 06-Aug-18 & 995 & 1500 & 20-Aug-18 & $51 \%$ & $-3 \%$ \\
\hline MAIN & 11-Jan-19 & 1380 & 1750 & 25-Jan-19 & $27 \%$ & $2 \%$ \\
\hline MAIN & 16-Nov-20 & 620 & 765 & 14-Dec-20 & $23 \%$ & $27 \%$ \\
\hline MCAS & 07-Mar-18 & 2470 & 3070 & 19-Apr-18 & $24 \%$ & $0 \%$ \\
\hline MCAS & 08-Feb-19 & 3322 & 3660 & 18-Feb-19 & $10 \%$ & $0 \%$ \\
\hline MCAS & 08-Jun-20 & 1050 & 1705 & 03-Jul-20 & $62 \%$ & $48 \%$ \\
\hline MCAS & 02-Nov-20 & 2050 & 2600 & 26-Nov-20 & $27 \%$ & $10 \%$ \\
\hline PNBN & 15-Oct-18 & 1010 & 1480 & 13-Feb-19 & $47 \%$ & $12 \%$ \\
\hline TINS & 06-Feb-18 & 965 & 1160 & 27-Feb-18 & $20 \%$ & $2 \%$ \\
\hline TINS & 12-Jun-20 & 560 & 1030 & 11-Nov-20 & $84 \%$ & $78 \%$ \\
\hline TKIM & 13-Feb-18 & 4090 & 6220 & 28-Feb-18 & $52 \%$ & $0 \%$ \\
\hline TKIM & 21-Mar-18 & 5525 & 9200 & 23-Apr-18 & $67 \%$ & $0 \%$ \\
\hline TKIM & 15-May-18 & 9900 & 12575 & 23-May-18 & $27 \%$ & $-1 \%$ \\
\hline TKIM & 14-Jan-19 & 2513 & 13011 & 08-Feb-19 & $4 \%$ & $3 \%$ \\
\hline TKIM & 10-Sep-20 & 6055 & 10115 & 07-Dec-20 & $67 \%$ & $64 \%$ \\
\hline
\end{tabular}

\section{CONCLUSION AND RECOMMENDATION}

Based on the above results, it can be concluded that:

1. To obtain investment return in IDX, technical analysis can be used by using EMA indicators to find the primary trend using weekly chart; Fibonacci retracement, Fibonacci external retracement, and Fibonacci projection to find buy and sell entry; and stochastic indicator to be used as secondary confirmation if needed.

2. By implementing this strategy, we can achieve cumulative return $165 \%$ for 3 years periods while IDX cumulative return is $0.05 \%$ for $2018-2020$ periods.

3. From total 73 trades during 2018-2020 periods, there are 10 trades that give negative returns; hence the accuracy of this method is $86 \%$, with notes that investors' psychological aspects are well maintained.

4. The best time to trade in IDX is when the trend is in bullish condition, it is not recommended to counter the trend while trading.

5. Bullish trend shall be confirmed first using weekly chart before making any buying position using daily chart. Decision for buy and sell position should utilize daily chart with clustering in Fibonacci retracement, Fibonacci projection indicator.

6 . The closest cluster is the potential strongest support and resistance. Fibonacci ratio used for buying position is $32.8 \%$, $50.0 \%$ and $61.8 \%$ and stochastic indicator is used as supplementary confirmation to Fibonacci strategy to verify its zone whether in overbought or in oversold zone.

7. To manage the risk in capital market, the daily individual investor should have technical analysis knowledge before making any positions in IDX and should have a trading strategy that consistently implemented.

\section{REFERENCES}

[1] Cnbcindonesia.com (2021). Viral Bunuh Diri Gegara Saham, Jadi Investor Harus Bagaimana? Retrieved July, $5^{\text {th }} 2021$ from https://www.cnbcindonesia.com/market/20210323114401-17232152/viral-bunuh-diri-gegara-saham-jadi-investor-harusbagaimana.

[2] Investor.id (2021). Gawat! Banyak Milenial Pakai Uang Kuliah dan Pinjol untuk 'Trading' Saham. Retrieved July, 5 2021 from https://investor.id/market-and-corporate/gawat-banyak-milenialpakai-uang-kuliah-dan-pinjol-untuk-trading-saham.

[3] Utami, W. (2017) Fundamental Versus Technical Analysis of Investment: Case Study of Investors Decision in Indonesia Stock Exchange. Journal of Internet Banking and Commerce Vol 22 (S8), 118.

[4] Indonesia Stock Exchange. (2021). IDX Statistical Highlights. Retrieved July, $19^{\text {th }} 2021$, from http://idx.co.id.

[5] Sjahrir, P.P., "Visioning IHSG 2030", presented at the Indonesia Investor Summit, June 26, 2021.

[6] Chung, C.Y. \& Wang, K. (2016). Short-term Trading by Individual Investors in the Korean Stock Market. Journal of the Asia Pacific Economy Vol 21 (4), 599-611.

[7] Yusgiantoro, I. (2018). Investors Behavior and Trading Strategies: Evidence from Indonesia Stock Exchange. OJK Research and Publications, 1-44.

[8] Petrusheva, N. \& Jordanoski, I. (2016) Comparative Analysis Between the Fundamental and Technical Analysis of Stocks. Journal of Process Management-New Technologies, International Vol 4 (2), 26-31.

[9] Pring, M.J. (2004). Technical Analysis Explained (5 ${ }^{\text {th }}$ ed.). McGrawHill Education.

[10] Hobbs, D.S. (2003). Fibonacci for the Active Trader. Trading Markets Publishing Group.

[11] Murphy, J.J. (1999). Technical Analysis of The Financial Markets. New York Institute of Finance.

[12] Dobson, E. D. (1984). Understanding Fibonacci Numbers (1 ${ }^{\text {st }}$ ed.). Traders Press, Inc.

[13] Ong, E. (2016). Technical Analysis for Mega Profit (2 $2^{\text {nd }}$ ed.). Jakarta: Gramedia.

[14] https://stockbit.com/\#/symbol/ACES/chartbit.

[15] https://stockbit.com/\#/symbol/BNLI/chartbit.

[16] https://stockbit.com/\#/symbol/BTPS/chartbit.

[17] https://stockbit.com/\#/symbol/WOOD/chartbit.

[18] https://stockbit.com/\#/symbol/ERAA/chartbit. 
Lusindah is a Facility Engineer in PT. Chevron

Pacific Indonesia and holds Master Degree on

Business Administration from SBM-ITB in 2021

majoring in General Management. Her Bachelor

Degree was from University of Indonesia in 2008

majoring in Electrical Engineering. Her interest is the

field of paper assets trading. She is also being the

founder and managed MBA SBM ITB Batch-7 stock

market investment community of practice. 